\title{
Comparison between Differently Synthesized Hydroxyapatite Composites for Orthopedic Applications
}

\author{
Kalinga Hapuhinna ${ }^{1}$, Rajitha Gunaratne ${ }^{1^{*}}$ (D) Jagath Pitawala ${ }^{2}$ \\ ${ }^{1}$ Department of Engineering Technology, Faculty of Technology, University of Sri Jayewardenepura, Nugegoda, Sri Lanka \\ ${ }^{2}$ Department of Science \& Technology, Faculty of Science \& Technology, Uva Wellassa University, Badulla, Sri Lanka \\ Email: ^rajitha@sjp.ac.lk
}

How to cite this paper: Hapuhinna, K., Gunaratne, R. and Pitawala, J. (2019) Comparison between Differently Synthesized Hydroxyapatite Composites for Orthopedic Applications. Journal of Materials Science and Chemical Engineering, 7, 16-28. https://doi.org/10.4236/msce.2019.75002

Received: April 7, 2019

Accepted: May 19, 2019

Published: May 22, 2019

Copyright () 2019 by author(s) and Scientific Research Publishing Inc. This work is licensed under the Creative Commons Attribution International License (CC BY 4.0).

http://creativecommons.org/licenses/by/4.0/

\begin{abstract}
Study carried to find out chemical and structural suitability of newly synthesized Eppawala hydroxyapatite composite varieties as bone cement, by comparing and contrasting them with human bone as well as commercially available bone cement, which is currently used in orthopedic surgeries. Commercially available methyl methacrylate (MMA) monomer used to reinforce solid state sintered and sol gel synthesized hydroxyapatite ceramic to prepare its composites as bone cements and their physical and chemical properties including composition, crystallinity, presence of functional groups, thermal stability, surface morphology, and microstructural features were examined compared to human bone. Results show there is a close similarity between synthesized products and human bone while credenting high thermal stability, good crystalline, and porous properties than the commercial product. Finally, study concluded newly synthesized composites can be applied directly as a substitution for commercial bone cement while having different properties from each other.
\end{abstract}

\section{Keywords}

Human Bone, Hydroxyapatite, Methyl Methacrylate, Orthopedics

\section{Introduction}

Hydroxyapatite is widely used as a bioceramic due to its close chemical and structural similarity with human hard tissues. It performs several outstanding properties: biocompatibility, non-inflammatory in nature, osteoconductivity, non-toxicity, bioactivity, etc. [1]-[6] As a result it has a range of biomedical ap- 
plications mainly in the fields of orthopedics and dentistry [7]-[20].

Here in this study we have synthesized hydroxyapatite by converting chloroapatite using sol gel technique-acidified route and solid state sintering method considering its ability to replace chlorine with other groups due to the increase of reactivity as its chlorine positions are under strain in the structural framework [21] [22]. Chloroapatite was collected from Sri Lankan Eppawala apatite deposit, which usually contains $34 \%-40 \%$ total phosphorus expressed as percentage of phosphorus pentoxide $\left(\mathrm{P}_{2} \mathrm{O}_{5}\right)$ [21] [22] [23] [24] [25]. Apart from that, for sol gel technique, ethanol and dil. nitric acid were used and for solid state sintering technique calcium hydroxide was used. Further synthesized hydroxyapatite is reinforced with a reactive resin, methyl methacrylate (MMA). It is a methyl ester of methacrylic acid. Polymerized forms of synthetic methacrylate resins used as cements in orthopedic and dentistry applications. Also it is able to fix prosthetic devices to bones and to cement bone to bone in difficult fractures as adhesives [26].

Selected commercial product majorly consists of zirconium dioxide and a liquid monomer methyl methacrylate (MMA) is currently used as fast curing bone cement in Sri Lankan government hospitals, which indicates for stable attachment of total or partial joint endoprostheses in bone, filling and stabilization bone defects within the scope of internal fixation treatment or for endoprosthes revision surgery and primary and secondary coverage of skull bone defects. It is prepared directly before use by mixing its powder component with liquid monomer component clinically. As a result ductile dough forms which cure within a few minutes [27].

As this study designed only to find out the possibility of substituting newly synthesized ceramic composites into human bone and to compare two different methods for synthesizing the same composite, we have only considered structural suitability of ceramic composite as bone cements.

\section{Methodology}

\subsection{Sample Preparation}

Natural raw apatite mineral were collected from the Eppawala apatite site. Then they were sorted as high grade rock phosphate (HERP) by the visual appearance of less coated apatite. After removing mud, collection of Apatite rocks were dried under sunlight, crushed using a jaw crusher (Serial no: 1720011, China) into small crystals/powder, grind further into micron/Nano level HERP powder using a planetary ball mill (XQM-4.0A) and sieved using sieve set (A060_01AC/0219, Scotland). Less than 63 micron range particle size powder were collected and oven dried at a temperature less than $150^{\circ} \mathrm{C}$ for $5 \mathrm{hrs}$ to prepare moisture removed HERP powder (MHERP). MHERP was taken as the raw material for synthesizing hydroxyapatite using both methods.

A sol gel synthesized Eppawala hydroxyapatite (SGHAp) was prepared under sol gel technique acidified route using MHERP, absolute ethanol, and diluted 
acid as the raw materials, as mentioned in the Equation (1). Mixture of MHERP and dil. acid (1:1 ratio) was stirred well in absolute ethanol medium for 4 - 6 hrs until the formation of gel. Then it was oven dried to a temperature less than $120^{\circ} \mathrm{C}$ for $15 \mathrm{hrs}$ and again two stage heat sintering were done starting from $400^{\circ} \mathrm{C}$ to $750^{\circ} \mathrm{C}$ for $8 \mathrm{hrs}$ [12] [22]. Finally the synthesized ceramic powder was mixed with commercial methyl methacrylate (MMA) liquid monomer until a paste forms to prepare sol gel hydroxyapatite composite.

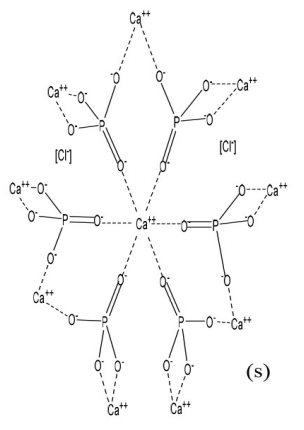

Choloroapatite

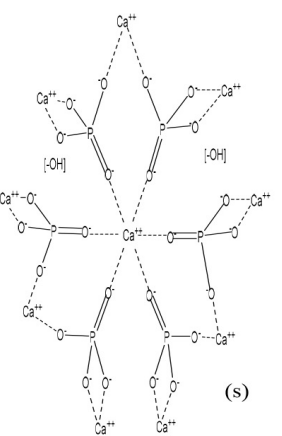

Hydroxyapatite

Solid state sintered composite sample was prepared as mentioned bellow. MHERP powder was added with needed weight of $\mathrm{Ca}(\mathrm{OH})_{2}$ powder, after well mixing, sieving and high temperature heat treating solid state sintered Eppawala hydroxyapatite powder (SSHAp) was synthesized according to Equation (2) [12] [22]. Then the synthesized ceramic powder was mixed with commercial methyl methacrylate (MMA) liquid monomer, until the ductile dough forms.

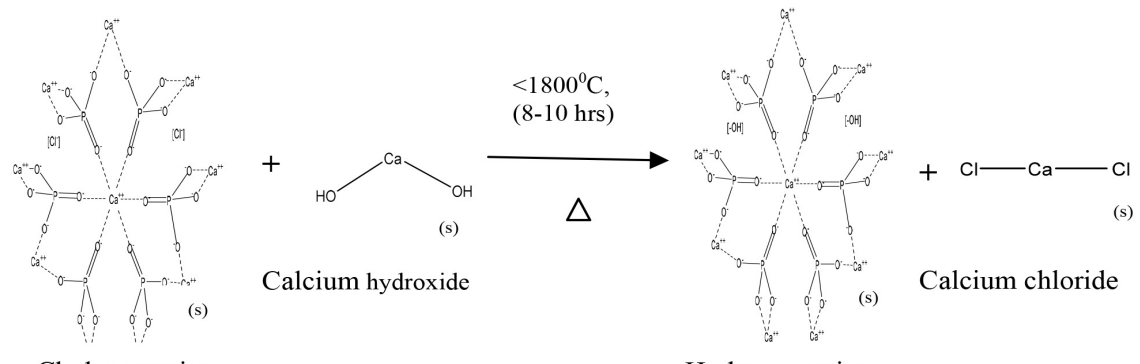

As the third step, commercial cement powder and liquid monomer were mixed together until the ductile dough forms, to obtain its composite.

\subsection{Sample Characterization}

Before mixing with the liquid monomer, commercial bone cement, and raw Eppawala hydroxyapatite was examined under X-ray fluorescence Spectroscopy (Rigaku XRF Spectrometer) to find out its elementary composition and presence 
of impurities liquid monomer was examined with Fourier Transform Infrared Spectroscopy (Bruker-Alpha FTIR Spectroscopy) ATR mode to confirm its composition. Then sample mixtures of newly prepared bone cements and the sample mixture of commercial bone cement were characterized using XRD, FTIR, TGA, and SEM with EDS techniques together with the human bone sample. The crystallographic phases of samples were determined by X-ray diffractometer (Rigaku-Ultima. IV diffractometer) in reflection mode with $\mathrm{Cu}$ Ka1: 0.154 $\mathrm{nm}$ radiation. $1.5^{\circ} \mathrm{min}^{-1}$ scanned speed was used to collect data within a $2 \theta$ range from $15^{\circ}$ to $80^{\circ}$. The presence of functional groups was confirmed by using Fourier Transform Infrared Spectroscopy (Bruker-Alpha FTIR Spectroscopy). The FTIR spectra were obtained over the region $400-4000 \mathrm{~cm}^{-1}$ using $\mathrm{KBr}$ pellet technique. The resolution of the spectrometer was $4 \mathrm{~cm}^{-1}$. The surface morphology and microstructural features of samples were studied using Hitachi SU6600 Analytical Variable Pressure FE-SEM (Field Emission Scanning Electron Microscope) and Oxford Instruments EDX with AZtec software. Furthermore, Thermogravimetric analysis (TGA) was done using a Thermal Analyzer (SDT Q600) with $\mathrm{N}$ environment, $10^{\circ} \mathrm{C} \cdot \mathrm{min}^{-1}$ heating rate, and $1450^{\circ} \mathrm{C}$ maximum temperature to find out the thermal stability of samples.

\section{Results and Discussion}

Both sol gel synthesized Eppawala hydroxyapatite (SGHAp) and solid state sintered Eppawala hydroxyapatite (SSHAp) powder contain $\mathrm{Ca}, \mathrm{P}$ and $\mathrm{O}$ include in higher weight percentages and $\mathrm{Fe}, \mathrm{Al}$ and $\mathrm{Si}$ as the impurities with hexagonal crystal structure showing a close similarity with mammalian bones and consists of many correlated, microcrystalline structures/particles/spherulites while credenting good thermal stability. Specially, SSHAp powder interprets porous properties and SGHAp powder interprets highly crystalline structure [12] [22].

Commercial bone cement sample contains $\mathrm{Zr}$ and $\mathrm{S}$ in higher amounts and $\mathrm{Hf}$ in fewer amounts as mentioned in Table 1. When comparing to the literature, there is a difference between commercial bone cement with bone ash meal, as it contains $54.14 \% \mathrm{CaO}, 38.03 \% \mathrm{P}_{2} \mathrm{O}_{5}$ and 0 to $0.9 \% \mathrm{Fe}_{2} \mathrm{O}_{3}, \mathrm{SiO}_{2}, \mathrm{Al}_{2} \mathrm{O}_{3}$ [27] and previous research findings show that SSHAp and SGHAp have similarity with bone ash in composition [12] [22].

Results of SEM with EDS Analysis for SGHAP with MMA mixture, SSHAP with MMA mixture, commercial bone cement with MMA mixture and human bone are indicated in Table 2. According to those results; SGHAp with MMA sample contains $\mathrm{O}$ in higher amounts and $\mathrm{C}, \mathrm{Ca}, \mathrm{P}, \mathrm{Cl}$ in order with least amount of Fe. SSHAp with MMA sample contains $\mathrm{O}, \mathrm{Ca}$ in higher amounts and then $\mathrm{P}, \mathrm{C}, \mathrm{Cl}$ in order. $\mathrm{Fe}$ also found in very less amount as an impurity. In the commercial product $\mathrm{O}$ and $\mathrm{C}$ carried in higher amounts and then $\mathrm{Ca}, \mathrm{Zr}, \mathrm{S}$, and $\mathrm{P}$ in order. When consider human bone $\mathrm{O}$ presence as the highest amount and then $\mathrm{C}, \mathrm{Ca}, \mathrm{P}$ and $\mathrm{Na}$ presence in descending order. $\mathrm{Na}, \mathrm{Mg}, \mathrm{Al}, \mathrm{Si}, \mathrm{S}, \mathrm{Fe}$ presence in very fewer amounts. It performs composition similarity with the mixtures 
Table 1. XRF results for commercial bone cement.

\begin{tabular}{ccccccc}
\hline Element & Spot 1 & Spot 2 & Spot 3 & Spot 4 & Spot 5 & Spot 6 \\
\hline & Mass \% & Mass \% & Mass \% & Mass \% & Mass \% & Mass \% \\
$16 \mathrm{~S}$ & 8.84 & - & - & 10.32 & - & - \\
$40 \mathrm{Zr}$ & 87.65 & 96.19 & 96.43 & 86.00 & 96.56 & 96.45 \\
$72 \mathrm{Hf}$ & 3.51 & 3.81 & 3.57 & 3.67 & 3.44 & 3.55 \\
\hline
\end{tabular}

Table 2. SEM with EDS results for SSHAp with MMA mixture, SGHAp with MMA mixture, Commercial bone cement with MMA mixture and Human bone.

\begin{tabular}{ccccc}
\hline Element & $\begin{array}{c}\text { SSHAp with MMA } \\
\text { mixture (wt\%) }\end{array}$ & $\begin{array}{c}\text { SGHAp with MMA } \\
\text { mixture (wt\%) }\end{array}$ & $\begin{array}{c}\text { Commercial product with } \\
\text { MMA mixture (wt\%) }\end{array}$ & $\begin{array}{c}\text { Human bone } \\
\text { (wt\%) }\end{array}$ \\
\hline $\mathrm{O}$ & 56.8 & 61.3 & 72.0 & 63.1 \\
$\mathrm{Ca}$ & 20.2 & 18.2 & 0.1 & 19.5 \\
$\mathrm{C}$ & 14.4 & 16 & 26.9 & 17.1 \\
$\mathrm{P}$ & 8.3 & 8.5 & 0.03 & 8.9 \\
$\mathrm{Cl}$ & 0.8 & 0.6 & - & - \\
$\mathrm{Zr}$ & - & - & 0.9 & - \\
$\mathrm{Fe}$ & 0.1 & 0.03 & - & 0.03 \\
$\mathrm{~S}$ & - & - & 0.1 & 0.03 \\
$\mathrm{Na}$ & - & - & - & 0.26 \\
$\mathrm{Mg}$ & - & - & - & 0.13 \\
\hline
\end{tabular}

of SSHAp with MMA and SGHAp with MMA and among synthesized hydroxyapatite composite varieties Ca amount is higher SSHAp with MMA that may due to the addition of calcium hydroxide at the beginning for preparation of ceramic. These results predict that synthesized hydroxyapatite composites rich with Ca, P similarly to healthy human hard tissues. SGHAp with MMA mixture interprets more similarity to human bone in composition than SSHAp with MMA mixture.

Considering Figures 1-4; SEM images of all mixtures and human bone show that there are good correlations of particles. SSHAp with MMA mixture and human bone only carried out micropores as shown in Figure 1. Porosity would be helpful for bone ingrowth as well as for good blood circulation. Presence of some different particles shaped in ball with some rough surface, was found in commercial bone cement mixture which may lead to have higher surface area as mentioned in Figure 2. According to Figure 1, Figure 2 \& Figure 4, some crystalline property can be found in both human bone, SSHAp with MMA and SGHAp with MMA mixtures. Among them crystallinty is higher in SGHAp mixture.

Figure 5 shows the resulted graph for liquid monomer it has coincided with the FTIR characteristic graph for methyl methacrylate (MMA) monomer. It interprets several peaks related to stretching vibrations including a sharp intense 


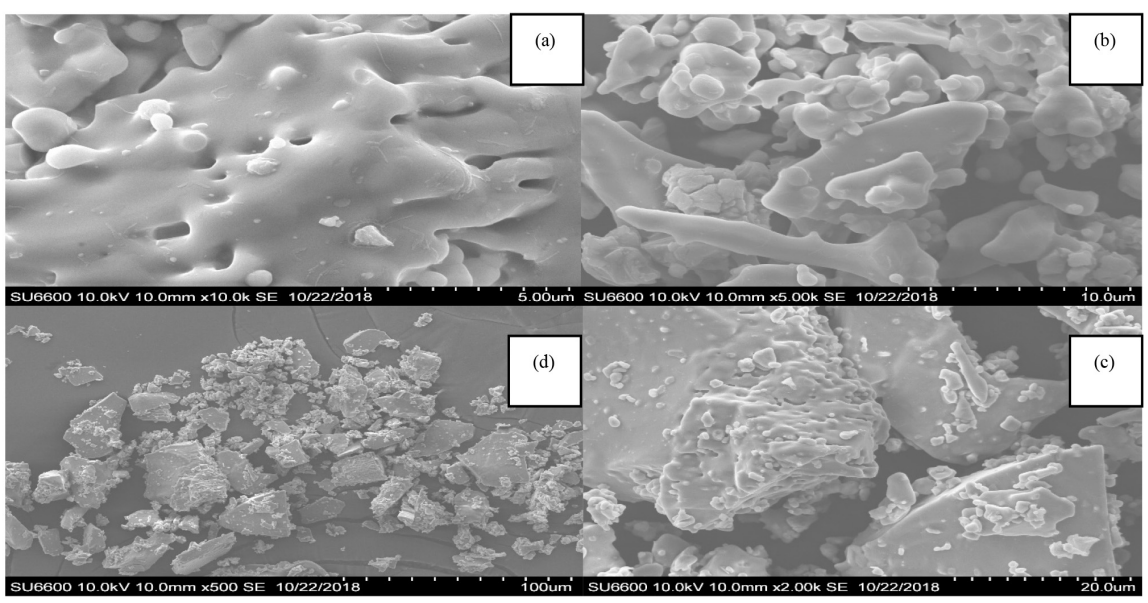

Figure 1. SEM images for SSHAp ceramic + MMA mixture, $10.0 \mathrm{kv}$, (a) $10 \mathrm{~K}$ (b) $5 \mathrm{KX}$ (c) $2 \mathrm{KX}(\mathrm{d}) 500 \mathrm{X}$.

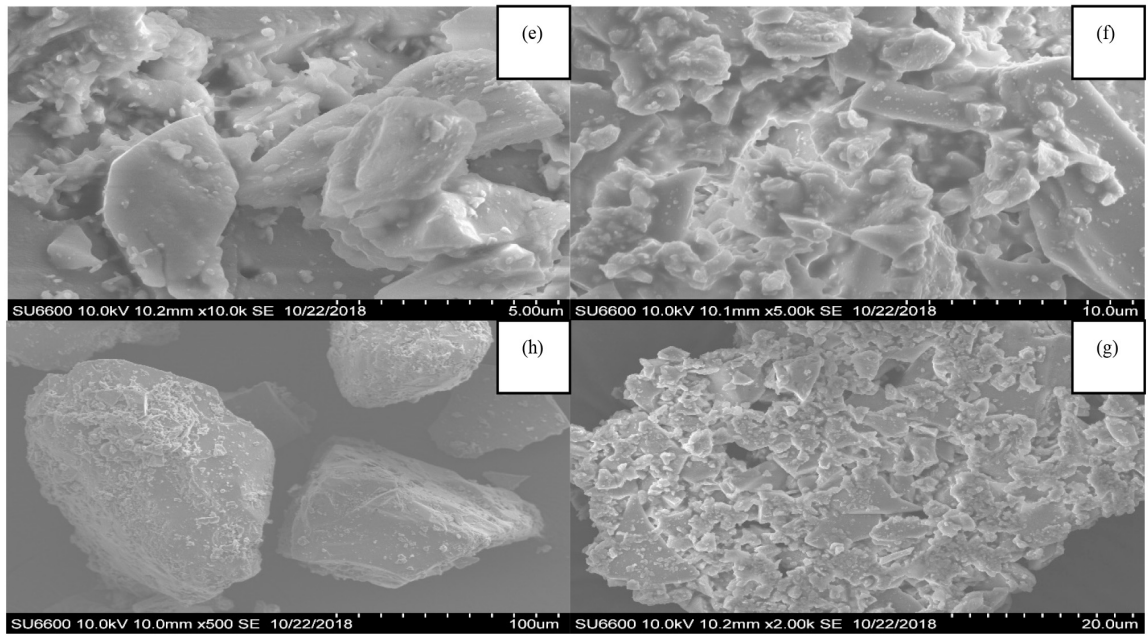

Figure 2. SEM images for SGHAp ceramic + MMA mixture, $10.0 \mathrm{kv}$, (e) $10 \mathrm{~K}$ (f) $5 \mathrm{KX}$ (g) $2 \mathrm{KX}(\mathrm{h}) 500 \mathrm{X}$.

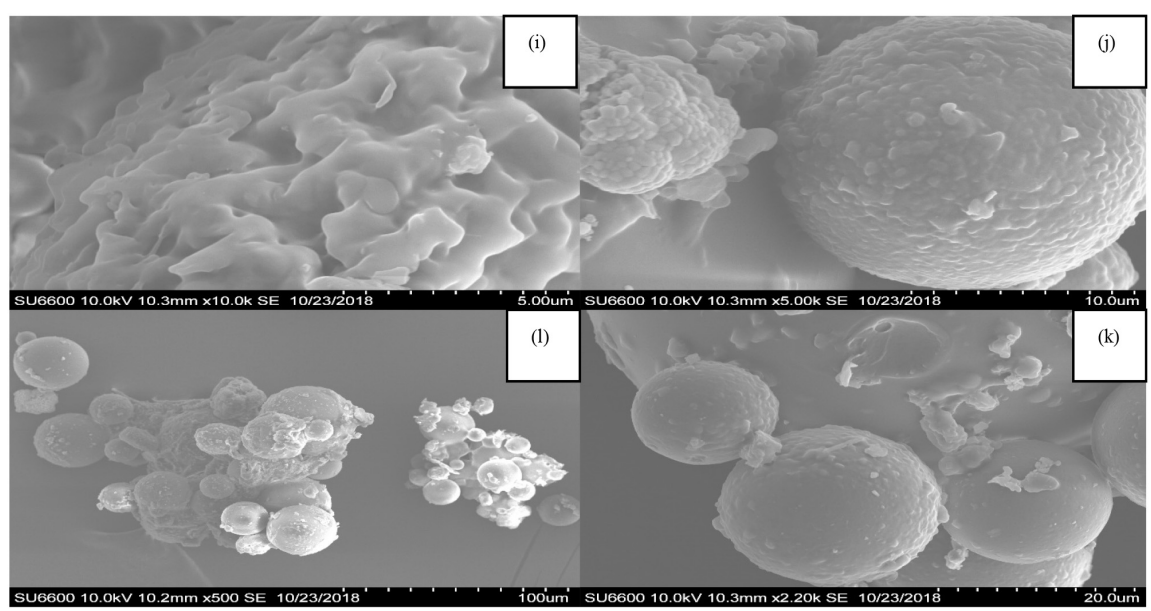

Figure 3. SEM images for Commercial bone cement + MMA mixture, $10.0 \mathrm{kv}$, (i) $10 \mathrm{~K}$ (j) $5 \mathrm{KX}(\mathrm{k}) 2 \mathrm{KX}$ (l) $500 \mathrm{X}$. 


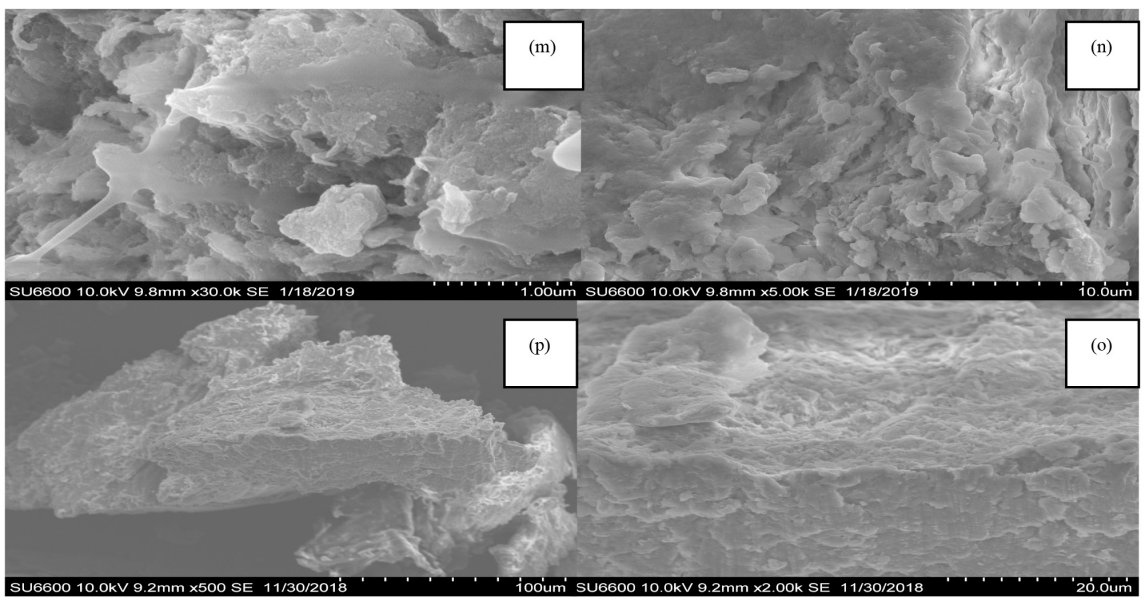

Figure 4. SEM images for human bone, $10.0 \mathrm{kv}$, (m) $10 \mathrm{~K}$ (n) $5 \mathrm{KX}$ (o) $2 \mathrm{KX}$ (p) $500 \mathrm{X}$.

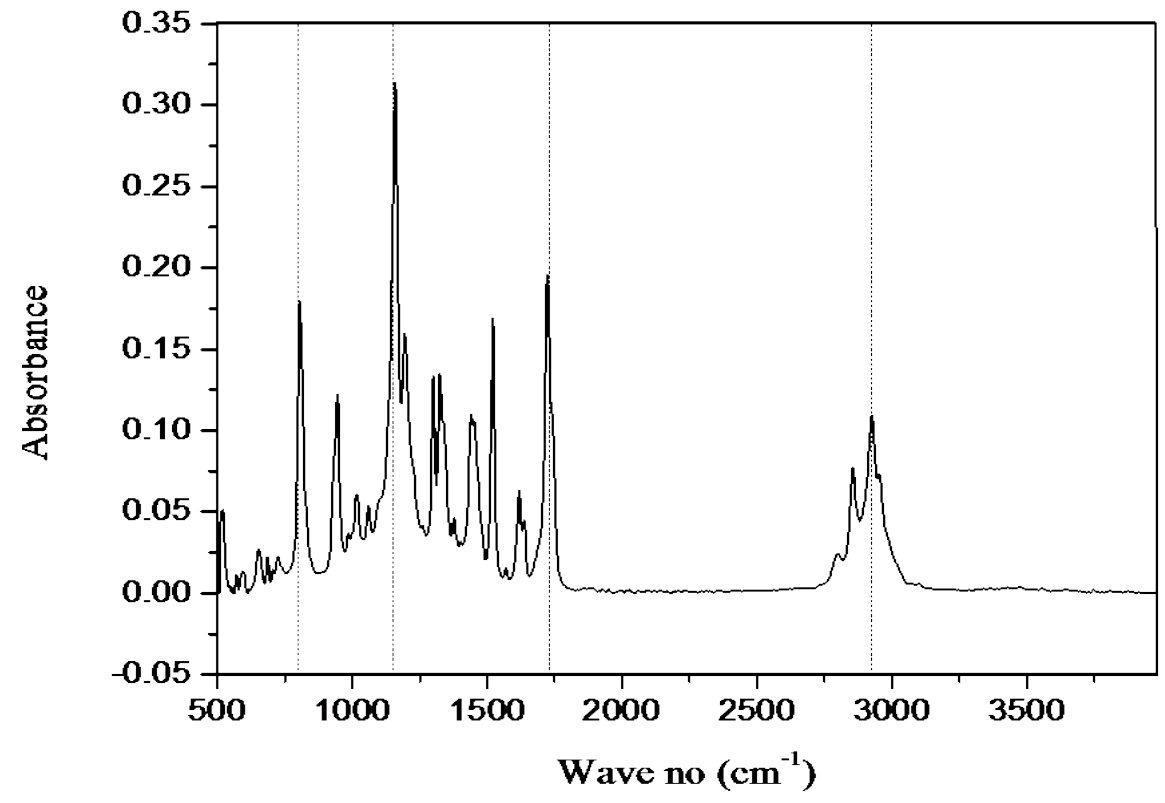

Figure 5. FTIR graph for liquid monomer.

peak at $1731 \mathrm{~cm}^{-1}$ related to the presence of ester carbonyl group, broad peak nearly $1150 \mathrm{~cm}^{-1}$ due to the $\mathrm{C}-\mathrm{O}$ (ester bond) and a peak nearly $800 \mathrm{~cm}^{-1}$ is due to the bending of $\mathrm{C}-\mathrm{H}$. Also literature shows the broad peak ranging from 3100 $2900 \mathrm{~cm}^{-1}$ is owing to the presence of stretching vibration. [28] As shown in Figure 6, all peaks for phosphate groups in the $560 \mathrm{~cm}^{-1}, 640 \mathrm{~cm}^{-1}, 963 \mathrm{~cm}^{-1}, 1028$ $\mathrm{cm}^{-1}$ and $1110 \mathrm{~cm}^{-1}$ wave no range and characteristic peak for $\mathrm{OH}^{-} /$hydroxyapatite nearly $3572 \mathrm{~cm}^{-1}$ wave no appeared in the human bone as well as the SSHAp with MMA and SGHAp with MMA mixtures [12] [22]. It confirms that even after the mixing with a monomer, the presence of hydroxyapatite in the SSHAp and SGHAp products. When considering commercial product mixture, it shows peak nearly $3572 \mathrm{~cm}^{-1}$ wave no range, which may due to the presence of $\mathrm{OH}^{-}$group, but that couldn't be identified as hydroxyapatite characteristic 


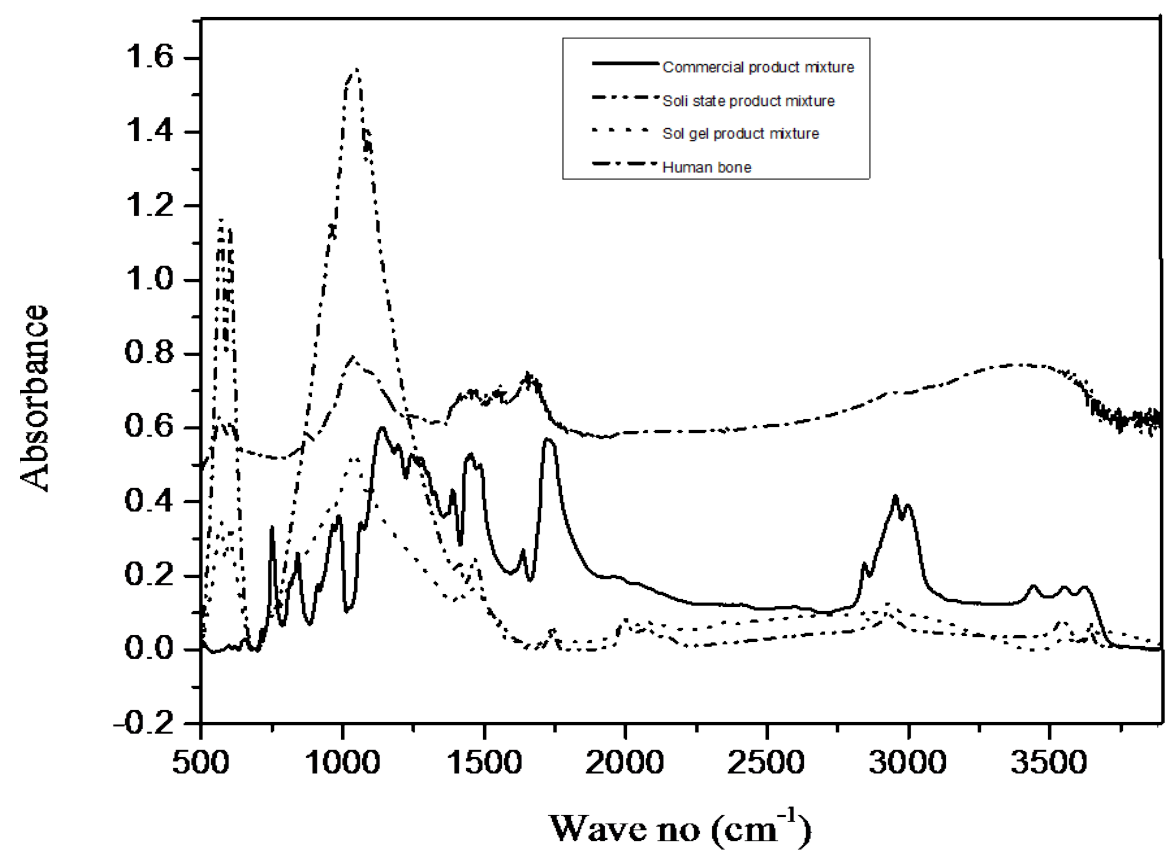

Figure 6. FTIR comparison for Commercial Bone cement with MMA mixture, SSHAp with MMA mixture, SGHAp with MMA mixture and Human bone.

peak, as no peaks found related to phosphate groups. Peaks related to MMA can be found within the commercial product, SSHAp and SGHAp mixtures as well.

Figure 7(a) \& Figure 7(b), explain even after mixing MMA monomer, XRD results of both SSHAp and SGAHAp mixtures contain all characteristic peaks related to the crystallographic phases $002,210,211,112,300,202,310,222,213$ and 004 of hexagonal hydroxyapatite, which shows similarity to human bone. Figure 7(c), carries the XRD results for commercial bone cement and it has interpreted all the peaks related to $110,111,111,002,200,102,211,022,122,300$, 013, 302, 113 and 222 crystallographic phases of monoclinic zirconium dioxide crystal structure with $84.1 \%$ crystallinity. Comparing those results with the literature, it can be confirmed that both human bone and synthesized hydroxyapatite composites interpret structural similarity via consisting hexagonal hydroxyapatite except for commercial product. Among them SGHAp with MMA mixture contains more crystalline properties than SSHAp with MMA mixture, as it contains $96 \%$ crystallinity and SGHAp mixture contains $99.41 \%$ crystallinity [12] [22] [29] [30] [31].

When comparing TGA results for human bone, commercial bone cement with MMA mixture, SSHAp with MMA mixture and SGHAp with MMA mixture according to Figure 8, human bone, SSHAp and SGHAp mixtures have shown the same pattern of weight loss, which was slightly different from commercial product mixture. At the beginning they show weight losses nearly $100^{\circ} \mathrm{C}$ to $400^{\circ} \mathrm{C}$ which may associate with the dehydration of samples, following that again samples have reduced their weight nearly $600^{\circ} \mathrm{C}$ to $700^{\circ} \mathrm{C}$ which may occur due to the gas elimination. Then again from $700^{\circ} \mathrm{C}$ up to $1400^{\circ} \mathrm{C}$ weight 


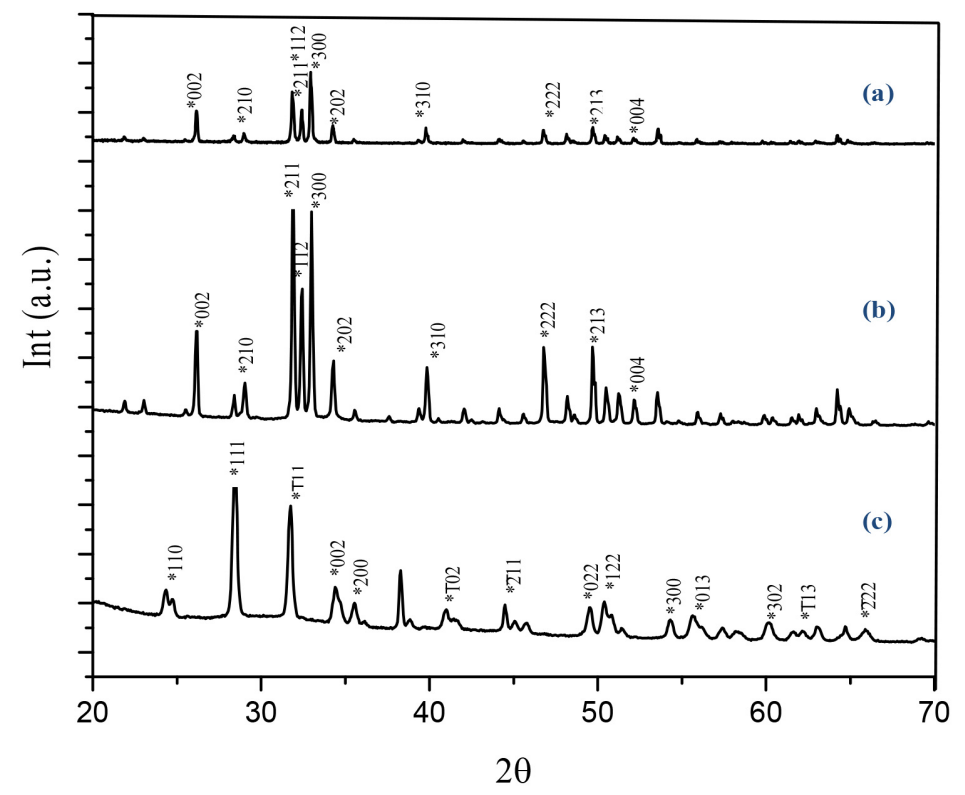

Figure 7. XRD pattern for (a) SGHAp with MMA mixture (b) SSHAp with MMA mixture (b) Commercial bone cement with MMA mixture.

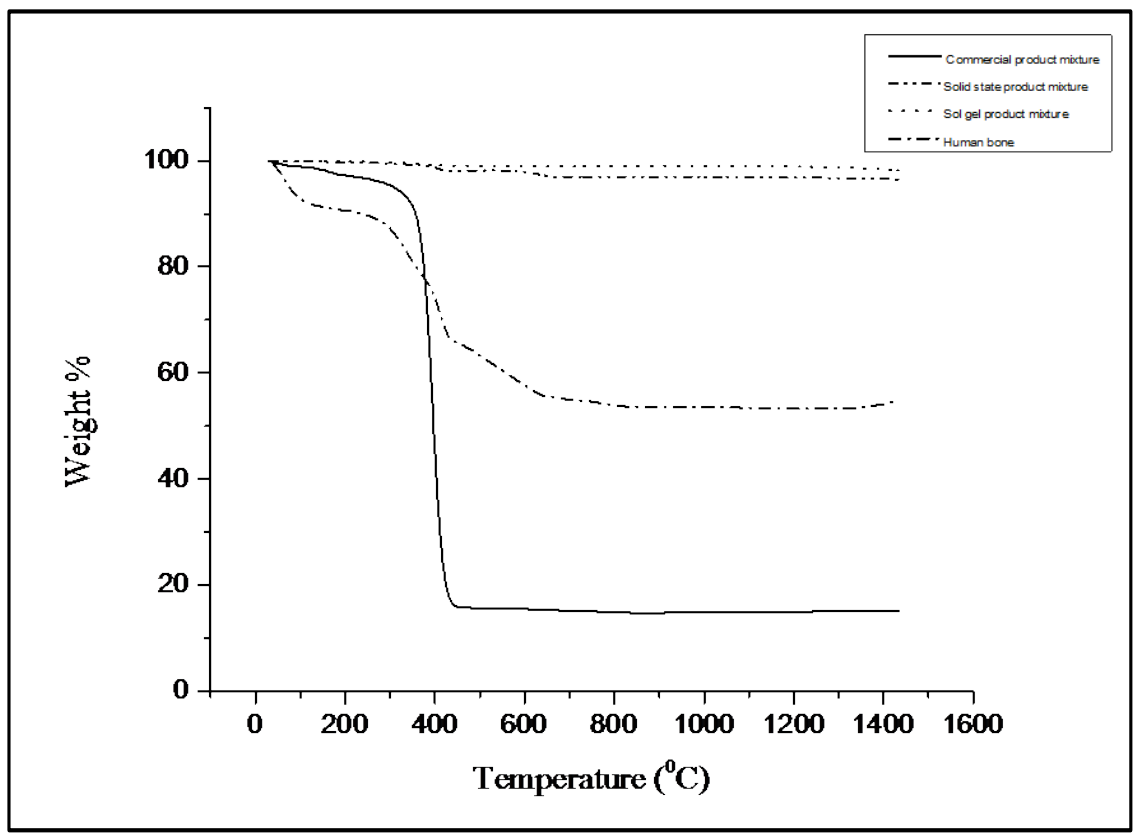

Figure 8. Comparison between TGA results of Human bone, Commercial bone cement mixture, Solid state product mixture and Sol gel product mixture.

losses have occurred due to the incipient transformation of produced hydroxyapatite in $\beta$-TCP [12] [22] [29] [32]. Therefore, it indicates the formation of hydroxyapatite in products as well as in human bone. Those results confirm the composition similarity of human bone and synthesized composite mixtures, as they were containing hydroxyapatite.

Also due to the least amount of weight loss in synthesized composite mixtures 
than human bone and commercial product mixtures, it can be concluded that the synthesized SSHAp with MMA and SGHAp with MMA mixtures perform high thermal stability and good material stability in nature and application.

Apart from these results, literature have evidenced that, hydroxyapatite in cooperated methyl methacrylate (MMA)/poly methyl methacrylate (PMMA) composites givegood thermal stability as well as having improved mechanical properties such as tensile strength, impact strength, fracture toughness, wear resistance etc. [33]-[38].

\section{Conclusions}

The study concludes that SSHAp with MMA and SGHAp with MMA composites have chemical and structural similarities with human bone and performs high thermal stability and good material stability in nature. Among them, SSHAp with MMA composite has shown more similarity to human bone in composition. SSHAp composite interprets microporous structure with less than 50 micron range particles which may lead to osteoconductive properties and SGHAp composite consists of highly crystalline particles. Therefore, both resulted composites can be used as a direct substitution for bone cement. Also it can be concluded that, when synthesizing composites, the brittleness of hydroxyapatite varieties as ceramics has been reduced by increasing ductile properties via addition of MMA.

Further aging properties and mechanical properties include tensile and impact strengths of these synthesized hydroxyapatite varieties to be studied in future. Also 3D printing technique will be applied to build implants from these materials.

\section{Conflicts of Interest}

The authors declare no conflicts of interest regarding the publication of this paper.

\section{References}

[1] Kalita, S.J., Bhardwaj, A. and Bhatt, H.A. (2007) Nanocrystalline Calcium Phosphate Ceramics in Biomedical Engineering. Materials Science and Engineering. $C$, 27, 441-449. https://doi.org/10.1016/j.msec.2006.05.018

[2] Rivera-Muñoz, E.M. (2011) Hydroxyapatite-Based Materials: Synthesis and Characterization. In: Fazel-Rezai, R., Ed., Biomedical Engineering-Frontiers and Challenges, IntechOpen, London, 79-95. https://doi.org/10.5772/19123

[3] Orlovskii, V.P., Komlev, V.S. and Barinov, S.M. (2002) Hydroxyapatite and Hydroxyapatite-Based Ceramics. Inorganic Materials, 38, 973-984. http://www2.chemia.uj.edu.pl/ skorska/Biomaterialy/hap/Orlovskii.pdf

[4] Mostafa, N.Y. and Brown, P.W. (2007) Computer Simulation of Stoichiometric hydroxyapatite: Structure and Substitutions. Journal of Physics and Chemistry of Solids, 68, 431-437. https://doi.org/10.1016/j.jpcs.2006.12.011

[5] Teixeira, S., Rodriguez, M.A., Pena, P., De Aza, A.H., De Aza, S., Ferraz, M.P., et al. 
(2009) Physical Characterization of Hydroxyapatite Porous Scaffolds for Tissue Engineering. Materials Science and Engineering: C, 29, 1510-1514. https://doi.org/10.1016/j.msec.2008.09.052

[6] FLUIDINOVA (2017) Hydroxyapatite: Properties, Uses and Applications. Zobnenovice Review.

https://www.fluidinova.com/hydroxyapatite-properties-uses-and-applications

[7] Guo, L., Huang, M. and Zhang, X. (2003) Effects of Sintering Temperature on Structure of Hydroxyapatite Studied with Rietveld Method. Journal of Materials Science: Materials in Medicine, 14, 817-822. https://doi.org/10.1023/A:1025048724330

[8] Thamaraiselvi, T.V., Prabakaran, K. and Rajeswari, S. (2006) Synthsis of Hydroxyapatite that Mimic Bone Mineralogy. Trends in Biomaterials and Artificial Organs, 19, 81-83.

[9] Shikhanzadeh, M. (1998) Direct Formation of Nanophase Hydroxyapatite on Cathodically Polarized Electrodes. Journal of Materials Science: Materials in Medicine, 9, 67-72.

[10] (2017) Case Study: Polymer Matrix Composites in Automobiles. https://www.princeton.edu/ ota/disk2/1988/8801/880110.PDF

[11] (2017) Innovative Materials for Innovative Automobiles. https://www.ceramtec.com/files/ca_innovative_materials_for_innovative_automobi les.pdf

[12] Hapuhinna, H., Gunaratne, R. and Pitawala, H. (2018) Development of a Biomaterial from Naturally Occurring Chloroapatite Mineral for Biomedical Applications. International Journal of Materials and Metallurgical Engineering, 12, 380-388.

[13] Wei, G. and Ma, P.X. (2004) Structure and Properties of Nanohydroxyapatite/Polymer Composite Scaffolds for Bone Tissue Engineering. Biomaterials, 25, 4749-4757. https://doi.org/10.1016/j.biomaterials.2003.12.005

[14] Aza, C.A. (2017) Composites in Automotive Applications: Review on Brake Pads and Discs. http://www.bristol.ac.uk/engineering/media/accis/cdt/news/aza.pdf

[15] García, D.B. (2017) Ceramic Matrix Composites-Manufacturing and Applications in the Automotive Industry.

https://www.bristol.ac.uk/engineering/media/accis/cdt/news/bracho-garcia.pdf

[16] (2017) Composite Manufacturing. http://www.ae.iitkgp.ernet.in/ebooks/chapter3.html\#kproj

[17] Nayak, A.K. (2010) Hydroxyapatite Synthesis Methodologies: An Overview. International Journal of Chem Tech Research, 2, 903-907.

http://sphinxsai.com/s_v2_n2/CT_V.2No.2/ChemTech_Vol_2No.2_pdf/CT=24\%20 (903-907).pdf

[18] Deptula, A., Lada, W., Olezak, T., Borello, A., Avani, C. and Dibartolomea, A. (1992) Preparation of Spherical Powders of Hydroxyapatite by Sol-Gel Processing. Journal of Non-Crystalline Solids, 147-148, 537-541. https://doi.org/10.1016/S0022-3093(05)80672-6

[19] Li, P. and de Groot, K. (1994) Better Bioactive Ceramics through Sol-Gel Process. Journal of Sol-Gel Science and Technology, 2, 797-801. https://doi.org/10.1007/BF00486353

[20] Balamurugan, A., Kannan, S., Selvaraj, V. and Rajeswari, S. (2004) Development and Spectral Characterization of Poly (Methyl Methacrylate)/Hydroxyapatite Composite for Biomedical Applications. Trends in Biomaterials and Artificial Or- 
gans, 18, 41-45. http://medind.nic.in/taa/t04/i1/taat04i1p41.pdf

[21] (2018) Nano Hydroxyapatite Powder.

https://www.chromspheres.com/nano-hydroxyapatite-powder

[22] Hapuhinna, H., Gunaratne, R., Pitawala, H., Wijesekara, K. and Ekanayake, E. (2017) Synthesis and Characterization of Hydroxyapatite from Eppawala Rock Phosphate for Biomedical Applications as a Value Added Product. Tradmed International (International Symposium on Traditional and Complementary Medicine).

[23] Anon (2017) Eppawala Rock Phosphate Deposit and Processing Plant. Wicky's Blog.

https://slminerals.blogspot.com/2015/09/eppawala-rock-phosphate-deposit-and.ht $\underline{\mathrm{ml}}$

[24] Gunawardane, R.P. (2003) Industries from Eppawala Phosphate Deposit. Daily News. http://archives.dailynews.lk/2003/03/07/fea13.html

[25] Ratnayake, S.P. and Navaratna, A.N. (2014) Spectroscopic Determination of Metal Impurities in Commercial Raw Material Fertiliser of Sri Lanka. Ceylon Journal of Science, 18, 27-36. https://www.researchgate.net/

[26] National Center for Biotechnology Information (2018) Methyl Methacrylate. PubChem Database. https://pubchem.ncbi.nlm.nih.gov/compound/methylmethacrylate

[27] (2018) PALACOS R + G (High Viscosity Bone Cement).

https://www.heraeus.com/media/media/hme/dochme/productshme/palacosbonece ment/rrgmvmvglvlvg/ifu/PALACOSRGIFU.pdf

[28] IFKA, T., Palou, M.T. and BazelovÁ, Z. (2012) The Influence of $\mathrm{CaO}$ and $\mathrm{P}_{2} \mathrm{O}_{5}$ of Bone Ash upon the Reactivity and the Burnability of Cement Raw Mixtures. Ceramics-Silikáty, 56, 76-84.

https://www.irsm.cas.cz/materialy/cs_content/2012/Ifka_CS_2012_0000.pdf

[29] Hapuhinna, H., Gunaratne, R. and Pitawala, H. (2018) Development of a Biomaterial from Naturally Occurring Chloroapatite Mineral for Biomedical Applications. International Journal of Chemical, Materials and Biomolecular Sciences, 11. https://doi.org/10.5281/zenodo.1340593

[30] Okada, M. and Matsumoto, T. (2015) Synthesis and Modification of Apatite Nanoparticles for Use in Dental and Medical Applications. Japanese Dental Science Review, 51, 85-95.

http://www.sciencedirect.com/science/article/pii/S1882761615000186

[31] Kumar, S., et al. (2015) Biofunctionalized Nanostructured Zirconia for Biomedical Application: A Smart Approach for Oral Cancer Detection. Advanced Science, 2, $1-9$.

https://www.researchgate.net/publication/277667321_Biofunctionalized_Nanostruc tured_Zirconia_for_Biomedical_Application_A_Smart_Approach_for_Oral_Cance r_Detection

[32] Miculescu, F. (2018) Complex Analysis on Heat Treated Human Compact Bones. UPB Scientific Bulletin, Series B: Chemistry and Materials Science, 73, 204-208. https://www.researchgate.net/publication/267710992_Complex_analysis_on_heat_t reated_human_compact_bones

[33] Caixeta, A.A.G., Pinheiro, N.R., Gonçalves, S.B. and Machado1, F. (2018) In Situ Formation of Methyl Methacrylate/Hydroxyapatite-Based Polymer Composites through a Sequential Bulk-Suspension Polymerization. https://www.alice.cnptia.embrapa.br/bitstream/doc/1005126/1/SilviaBelemNICE201 $\underline{42 . p d f}$ 
[34] Chow, W.S., Tay, H.K., Azlan, A. and Mohd-Ishak, Z.A. (2008) Mechanical and Thermal Properties of Hydroxyapatite Filled Poly (Methyl Methacrylate) Composites.

https://www.researchgate.net/publication/242208553_MECHANICAL_AND_THE RMAL_PROPERTIES_OF_HYDROXYAPATITE_FILLED_POLYMETHYL_MET HACRYLATE_COMPOSITES

[35] Moreno, K.J., et al. (2014) Preparation and Performance Evaluation of PMMA/HA Nanocomposite as Bulk Material. Journal of Composite Materials, 49, 1345-1353. https://journals.sagepub.com/doi/abs/10.1177/0021998314533713

[36] Serbetc, K., Korkusuz, F. and Hasirci, N. (2000) Mechanical and Thermal Properties of Hydroxyapatite-Impregnated Bone Cement. Turkish Journal of Medical Sciences, 30, 543-549.

https://pdfs.semanticscholar.org/c36b/fcfc925f24f5cc995c320843bc7f03887fb3.pdf

[37] Santos, J.G.F., Pita, V.J.R.R., Melo, P.A., Nele, M. and Pinto, J.C. (2011) Production of Bone Cement Composites: Effect of Fillers, Co-Monomer and Particles Properties. Brazilian Journal of Chemical Engineering, 28, 229-241.

http://www.scielo.br/scielo.php?script=sci_arttext

[38] Zhang, X., Zhang, Y., Ma, G., Yang, D. and Nie, J. (2015) The Effect of the Prefrozen Process on Properties of a Chitosan/Hydroxyapatite/Poly(Methyl Methacrylate) Composite Prepared by Freeze Drying Method Used for Bone Tissue Engineering. RSC Advances, 5, 79679-79686.

https://pubs.rsc.org/en/content/articlelanding/2015/ra/c5ra14549j https://doi.org/10.1039/C5RA14549J 